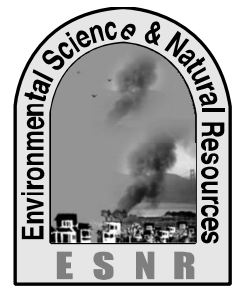

\title{
Forms and Placement of Nitrogen Fertilizers Influence Nitrogen Use Efficiency and Yield of BRRI Dhan49 under Continuous Flooded Condition
}

\author{
M. R. Islam ${ }^{\text {1* }}$ M. P. Akhter ${ }^{1}$, A. Huda ${ }^{2}$, M. A. Hashem ${ }^{1}$ and M. A. Asad ${ }^{2}$ \\ ${ }^{1}$ Department of Soil Science, Bangladesh Agricultural University, Mymensigh-2202 \\ ${ }^{2}$ Department of Soil Science, Sylhet Agricultural University, Sylhet-3100 \\ *Corresponding author: rafiqss69@bau.edu.bd
}

\begin{abstract}
An experiment was conducted at the Soil Science Field Laboratory of Bangladesh Agricultural University, Mymensingh during Aman season of 2016 to evaluate the effects of deep placement of $\mathrm{N}$ fertilizers in the form of USG and NPK briquettes in comparison with PU on nitrogen use efficiency and yield of BRRI dhan49. The soil was silt loam in texture having $\mathrm{pH}$ 6.27, organic matter content $1.95 \%$ and total $\mathrm{N} 0.136 \%$. The experiment was laid out in a RCBD with eight treatments and three replications. The PU was applied in three equal splits. The USG and NPK briquettes were deep placed at $10 \mathrm{DAT}$ and the briquettes were placed at $8-10 \mathrm{~cm}$ depth between four hills at alternate rows. The maximum grain yield of $5981 \mathrm{~kg} \mathrm{ha}^{-1}$ was recorded in $\mathrm{T}_{3}$ which was statistically similar with $\mathrm{T}_{2}$ and $\mathrm{T}_{6}$. The highest straw yield of $6381 \mathrm{~kg} \mathrm{ha}^{-1}$ was observed in $\mathrm{T}_{3}$. The lowest grain yield $\left(3265 \mathrm{~kg} \mathrm{ha}^{-1}\right)$ and straw yield $\left(4280 \mathrm{~kg} \mathrm{ha}^{-1}\right)$ was recorded in $\mathrm{T}_{3}$. The deep placement of USG and NPK briquettes enhanced both the recovery of applied $\mathrm{N}$ and $\mathrm{N}$ use efficiency in comparison with broadcast application of prilled urea.
\end{abstract}

Key words: BRRI dhan49, Nitrogen fertilizer, $\mathrm{T}$ aman rice

\section{Introduction}

Rice (Oryza sativa L) dominates Bangladesh agriculture sector covering $80 \%$ of the total cropped area of the country (AIS, 2008). Rice is grown in Bangladesh in three seasons namely aus, aman and boro. Among them aman rice covers the largest area of 9.82 million hectares with a production of 12.84 million tons (AIS, 2008). Present yield level of rice is not enough to meet the future demands due to low fertility level of soil. So, the researchers have to develop high yielding varieties and find out suitable management practices, especially, fertilizer management for the modern varieties. Nitrogen is the most important nutrient element for crop production. Farmers of Bangladesh use mainly urea in rice field as the most available source of nitrogen. Annual requirement of urea of the country is about 28 lakh ton of which $50 \%$ is met by the domestic production. The rest amount of urea needs to be imported by spending a large amount of foreign currency (BBS, 2008). The nitrogen use efficiency especially of urea fertilizer is very low (30-35\%) in rice cultivation (IFDC, 2007). Khalil et al. (2009) reported that the volatilization loss of prilled urea (PU) is very high and farmers lose a huge amount of money for $\mathrm{N}$ fertilizer and proposed that to control this loss, deep placement of fertilizer might be a good option to minimize the production cost as well as to increase crop yield. Bhuiyan et al. (1988) reported that deep point placement of USG produced significantly higher grain yield of rice than split application of PU. Excessive $\mathrm{N}$ fertilization is one of the major concerns in sustainable agriculture for its decreased $\mathrm{N}$-utilization efficiency by crops and increased $\mathrm{N}$ release to the environment, resulting atmosphere and water systems pollution (Zhu et al. 1997). This applied fertilizer is getting lost to the environment through a number of processes including immobilization, denitrification, volatilization, leaching and fixation resulting low crop yield and reduced efficiency of applied nutrients. Therefore, attention must be given to minimize the production cost in a search for increasing crop yield. A technology called fertilizer deep placement (FDP) is followed in Bangladesh, which ensures $40 \%$ more efficiency of urea utilization. Urea deep placement is a simple but a very effective technology which involves the placement of 1-3 grams of urea super granules or briquettes at a 7-10 centimeters $(\mathrm{cm})$ soil depth shortly after the paddy is transplanted. The UDP increases nitrogen use efficiency because most of the urea nitrogen stays in the soil, close to the plant roots where it is absorbed more effectively.

Deep placement of Urea Super Granule (USG) and NPK briquette increases $\mathrm{N}$ fertilizer use efficiency in wetland rice. The placement of USG at 8-10 $\mathrm{cm}$ depth of soil can save $30 \%$ nitrogen than prilled urea, increases nutrient absorption, improves soil health ultimately increases the 
crop yields (Savant et al. 1983). This not only improves fertilizer $\mathrm{N}$ use efficiency in flooded rice but also minimizes $\mathrm{N}$ loss resulting from ammonia volatilization and denitrification (Savantan et al. 1998; Mohanty, 1999). The USG dissolves slowly in the soil providing a steady supply of available $\mathrm{N}$ throughout the growing period of the crop. Kapoor et al. (2008) reported that broadcast application of $\mathrm{N}$ as urea resulted on an average 10 times higher amounts of ammonium $\mathrm{N}$ in flood water as compared to deep placement of urea and NPK briquette. Islam et al. (2017) demonstrated higher grain yield and $\mathrm{N}$ use efficiency of rice with the deep placement of $\mathrm{N}$ fertilizers. A good number of research works were conducted on $\mathrm{N}$ management and $\mathrm{N}$ use efficiency in rice but still there is a gap in data on deep placement of $\mathrm{N}$ fertilizers for maximizing rice yield and $\mathrm{N}$ use efficiency. The specific objectives of the present study were to evaluate the effect of deep placement of $\mathrm{N}$ fertilizers on the yield components, yield, $\mathrm{N}$ recovery and $\mathrm{N}$ use efficiency of BRRI dhan 49.

\section{Materials and Methods}

The experiment was carried out in the Soil Science Field Laboratory of Bangladesh Agricultural University, Mymensingh during the Aman season of 2016. The study was performed to evaluate the effects of deep placement of $\mathrm{N}$ fertilizers in the form of urea super granule (USG) and NPK briquettes in comparison with prilled urea (PU) on nitrogen use efficiency and yield of BRRI dhan 49 . The soil of the experimental site belongs to the Sonatala series under the AEZ of Old Brahmaputra Floodplain. The soil was silt loam in texture having $\mathrm{pH} 6.27$, organic matter content $1.95 \%$ and total $\mathrm{N} 0.136 \%$. The treatments were $\mathrm{T}_{1}$ (Control), $\mathrm{T}_{2}\left(\mathrm{PU}, 104 \mathrm{~kg} \mathrm{~N} \mathrm{ha}^{-1}\right), \mathrm{T}_{3}$ (USG, $104 \mathrm{~kg} \mathrm{~N} \mathrm{ha}^{-1}$ ), $\mathrm{T}_{4}$ (USG $78 \mathrm{~kg} \mathrm{~N} \mathrm{ha}^{-1}$ ), $\mathrm{T}_{5}$ (USG, $52 \mathrm{~kg} \mathrm{~N} \mathrm{ha}^{-1}$ ), $\mathrm{T}_{6}$ (NPK briquettes, $104 \mathrm{~kg} \mathrm{~N} \mathrm{ha}^{-1}$ ), $\mathrm{T}_{7}$ (NPK briquettes, $78 \mathrm{~kg} \mathrm{~N} \mathrm{ha}^{-1}$ ) and $\mathrm{T}_{8}$ (NPK briquettes, $52 \mathrm{~kg} \mathrm{~N} \mathrm{ha}^{-1}$ ). All the treatments except $\mathrm{T}_{6}, \mathrm{~T}_{7}$ and $\mathrm{T}_{8}$ received $16 \mathrm{~kg} \mathrm{P}$ and $42 \mathrm{~kg} \mathrm{~K} \mathrm{ha}^{-1} \mathrm{TSP}$ and MoP, respectively. In $T_{6}, T_{7}$ and $T_{8}$ treatments, $P$ and $K$ were supplied from NPK briquettes. BRRI dhan49, a high yielding variety of rice was used as a test crop. Forty day-old seedlings were transplanted in the plots maintaining a spacing of $20 \mathrm{~cm} \times 20 \mathrm{~cm}$. The experiment was laid out in a Randomized Complete Block Design (RCBD) with eight treatments and three replications. All the fertilizers except urea i.e. TSP, MoP, gypsum and zinc sulphate were applied as basal doses in all the plots at final land preparation. Prilled urea was applied in three equal splits. The USG and NPK briquettes were deep placed at 10 DAT and the briquettes were placed at 8-10 $\mathrm{cm}$ depth between four hills at alternate rows. The first dose of PU was applied at 10 days after transplanting (DAT); the second dose was added as top dressing at 35 DAT (active tillering stage) and the third dose was top-dressed at 55 DAT (panicle initiation stage). Intercultural operations such as irrigation, weeding, pest control etc. were done as and when required. The crop was harvested at maturity. The grain yield was assessed with $14 \%$ moisture basis while the straw yield was recorded on sundry basis. Five hills were selected randomly from each plot and data on plant height, tillers hill $^{-1}$, panicle length, grains panicle ${ }^{-1}$ and 1000-grain weight were recorded. The $\mathrm{N}$ content in rice grain and straw was determined by Semi-micro Kjeldahl method (Bremner and Mulvaney, 1982). Nitrogen uptakes, apparent nitrogen recovery and nitrogen use efficiency were calculated from $\mathrm{N}$ content and yield data. The collected data were analyzed statistically by F-test to examine the treatment effects and mean differences were examined by Duncanôs New Multiple Range Test (DMRT) (Gomez and Gomez, 1984).

\section{Yield components}

\section{Results and Discussion}

The results revealed that the yield components (plant height, panicle length, tillers hill ${ }^{-1}$ and grains panicle ${ }^{-1}$ ) of BRRI dhan49 responded significantly to deep placement of USG and NPK briquettes as compared to PU. The tallest plant of $91.07 \mathrm{~cm}$ was found in $\mathrm{T}_{3}$ (USG, $104 \mathrm{~kg}$ $\mathrm{N} \mathrm{ha}^{-1}$ ) which was identical to all other treatments except $\mathrm{T}_{1}$ (Control) and $\mathrm{T}_{2}$ (PU, $104 \mathrm{~kg} \mathrm{~N} \mathrm{ha}^{-1}$ ). The smallest plant $(72.33 \mathrm{~cm})$ was observed in $\mathrm{T}_{1}$ (Control). The highest panicle length $(25 \mathrm{~cm})$ was found in $\mathrm{T}_{3}$. The lowest panicle length (17.67) was observed in $T_{1}$. The number of grains panicle ${ }^{-1}$ varied from 128.33 to 156.67 with the highest value in $T_{3}$ which was identical with $T_{2}$. The treatment $\mathrm{T}_{3}$ (USG, $104 \mathrm{~kg} \mathrm{~N} \mathrm{ha}^{-1}$ ), produced the highest tillers hill ${ }^{-1}$ (16.33). The lowest value (9.67) was obtained in $\mathrm{T}_{1}$ (Control). The treatment $\mathrm{T}_{2}, \mathrm{~T}_{4}, \mathrm{~T}_{6}$ and $\mathrm{T}_{7}$ demonstrated statistically similar effective tillers hill $^{-1}$. The 1000-grain weight was not influenced significantly by the treatments. These results are in consistent with the findings of Das et al. (2015) and Islam et al. (2017) who reported that deep placement of $\mathrm{N}$ in the form of USG and NPK briquette enhanced the yield attributes of rice as compared to broadcast application of PU. 
Table 1. Effect of deep placement of $\mathrm{N}$ fertilizers in the form of USG and NPK briquettes as compared to PU on the yield components of BRRI dhan 49

\begin{tabular}{|c|c|c|c|c|c|}
\hline Treatments & $\begin{array}{|ll|}\text { Plant } & \text { height } \\
\text { (cm) } & \\
\end{array}$ & $\begin{array}{l}\text { Tillers } \\
\text { (no.) }\end{array}$ & \begin{tabular}{|l|} 
Panicle \\
length (cm)
\end{tabular} & \begin{tabular}{|l|} 
Grains \\
panicles $^{-1}$ (no.)
\end{tabular} & $\begin{array}{l}\text { 1000-grain } \\
\text { weight } \\
\text { (g) }\end{array}$ \\
\hline $\mathrm{T}_{1}$ (Control) & $72.33 \mathrm{f}$ & $9.67 \mathrm{e}$ & $17.67 f$ & $135.00 \mathrm{bc}$ & $35.64 b$ \\
\hline $\mathrm{T}_{2}\left(\mathrm{PU}, 104 \mathrm{~kg} \mathrm{~N} \mathrm{ha}^{-1}\right)$ & $85.57 \mathrm{bc}$ & $14.00 \mathrm{~b}$ & $23.00 \mathrm{~b}$ & $156.67 \mathrm{a}$ & $37.95 \mathrm{a}$ \\
\hline $\mathrm{T}_{3}$ (USG, $104 \mathrm{~kg} \mathrm{~N} \mathrm{ha}^{-1}$ ) & $91.07 \mathrm{a}$ & $16.33 a$ & $25.00 \mathrm{a}$ & $156.67 \mathrm{a}$ & $38.77 \mathrm{a}$ \\
\hline $\mathrm{T}_{4}\left(\mathrm{USG}, 78 \mathrm{~kg} \mathrm{~N} \mathrm{ha}^{-1}\right)$ & $87.00 \mathrm{~b}$ & $13.33 b c$ & $22.33 b$ & $147.67 \mathrm{ab}$ & $36.41 \mathrm{~b}$ \\
\hline $\mathrm{T}_{5}$ (USG, $52 \mathrm{~kg} \mathrm{~N} \mathrm{ha}^{-1}$ ) & $83.33 c$ & $12.00 \mathrm{~cd}$ & $20.33 d$ & $144.00 \mathrm{abc}$ & $36.79 b$ \\
\hline $\mathrm{T}_{6}$ (NPK briquette, $104 \mathrm{~kg} \mathrm{~N} \mathrm{ha}^{-1}$ ) & $84.67 \mathrm{bc}$ & $13.67 \mathrm{~b}$ & $22.90 \mathrm{~b}$ & $145.00 \mathrm{abc}$ & $37.91 \mathrm{a}$ \\
\hline $\mathrm{T}_{7}\left(\mathrm{NPK}\right.$ briquettes, $78 \mathrm{~kg} \mathrm{~N} \mathrm{ha}^{-1}$ ) & $81.00 \mathrm{~d}$ & $12.67 \mathrm{bcd}$ & $21.33 c$ & $136.67 \mathrm{bc}$ & $36.59 b$ \\
\hline $\mathrm{T}_{8}\left(\mathrm{NPK}\right.$ briquettes, $52 \mathrm{~kg} \mathrm{~N} \mathrm{ha}^{-1}$ ) & $78.33 \mathrm{e}$ & $11.33 \mathrm{~d}$ & $19.33 \mathrm{e}$ & $128.33 \mathrm{c}$ & $35.67 \mathrm{~b}$ \\
\hline CV\% & 1.57 & 6.14 & 2.36 & 6.18 & 1.69 \\
\hline $\mathrm{SE}( \pm)$ & 0.75 & 0.46 & 0.29 & 5.13 & 0.36 \\
\hline
\end{tabular}

Figures in a column having common letters do not differ significantly at $5 \%$ level of significance. $C V(\%)=$ Coefficient of variation; $S E( \pm)=$ Standard error of means

\section{Grain yield}

Significant response of the grain yield of BRRI dhan49 was found due to the deep placement of $\mathrm{N}$ fertilizers (Table 2). The grain yield ranged from 3265 to $5981 \mathrm{~kg}$ $\mathrm{ha}^{-1}$. The highest grain yield of $5981 \mathrm{~kg} \mathrm{ha}^{-1}$ was recorded in $\mathrm{T}_{3}$ (USG, $104 \mathrm{~kg} \mathrm{~N} \mathrm{ha}^{-1}$ ) which was statistically similar to $\mathrm{T}_{2}\left(\mathrm{PU}, 104 \mathrm{~kg} \mathrm{~N} \mathrm{ha}^{-1}\right.$ ) and $\mathrm{T}_{6}$ (NPK briquette, $\left.104 \mathrm{~kg} \mathrm{~N} \mathrm{ha}^{-1}\right)$. The lowest grain yield of $3265 \mathrm{~kg} \mathrm{ha}^{-1}$ was observed in $\mathrm{T}_{1}$ (Control). The percent increase of grain yield over control ranged from 56.19 to $83.18 \%$ (Figure 1). The maximum increase over control was found in $\mathrm{T}_{3}$ (USG, $104 \mathrm{~kg} \mathrm{~N} \mathrm{ha}{ }^{-1}$ ) and the minimum increase was noted in $\mathrm{T}_{8}$ (Table 2). Based on grain yield the treatments may be ranked in the order of $T_{3}>T_{6}>T_{2}>$ $T_{4}>T_{5}>T_{7}>T_{8}>T_{1}$. Deep placement of USG at the rate of $104 \mathrm{~kg} \mathrm{ha}^{-1}$ performed better in increasing grain yield of rice as compared to PU and NPK briquette. These findings are well corroborated with Kapoor et al. (2008) and Islam et al. (2011) who also observed increased rice yield due to application of USG and NPK briquettes. Islam et al (2017) also reported grain yield increase of
BRRI dhan 46 as a consequence of deep placement of $\mathrm{N}$ fertilizers.

\section{Straw yield}

Straw yield of BRRI dhan 49 responded significantly to different treatments under study. The highest straw yield of $6381 \mathrm{~kg} \mathrm{ha}^{-1}$ was found in $\mathrm{T}_{3}$ (USG, $104 \mathrm{~kg} \mathrm{~N} \mathrm{ha}^{-1}$ ) which was statistically similar with $\mathrm{T}_{2}, \mathrm{~T}_{4}$ and $\mathrm{T}_{6}$. The lowest straw yield of $4280 \mathrm{~kg} \mathrm{ha}^{-1}$ was observed in $\mathrm{T}_{1}$ (Control). Nearly 30.06 to $49.09 \%$ increase in straw yield over control was recorded due to application of $\mathrm{N}$ either broadcast or deep placed (Figure 1). As like as the grain yield, the maximum increase of straw yield over control was found in $\mathrm{T}_{3}$ (USG, $104 \mathrm{~kg} \mathrm{~N} \mathrm{ha}^{-1}$ ). Based on straw yield the treatments may be ranked in order of $T_{3}>T_{2}>$ $\mathrm{T}_{6}>\mathrm{T}_{4}>\mathrm{T}_{5}>\mathrm{T}_{7}>\mathrm{T}_{8}>\mathrm{T}_{1}$. Deep placement of USG @ 104 $\mathrm{kg} \mathrm{N} \mathrm{ha}^{-1}$ ) performed better than other treatments in increasing straw yield under flooded condition. These results are in agreement with Islam et al. (2017) and Shaha et al. (2018) who also found straw yield increase of rice due to deep placement of $\mathrm{N}$ fertilizers. 
Table 2. Yield of BRRI dhan 49 as influenced by the application of PU, USG and NPK briquettes

\begin{tabular}{|c|c|c|}
\hline Treatments & $\begin{array}{c}\text { Grain yield } \\
\left(\mathrm{kg} \mathrm{ha}^{-1}\right)\end{array}$ & $\begin{array}{c}\text { Straw yield } \\
\left(\mathrm{kg} \mathrm{ha}^{-1}\right)\end{array}$ \\
\hline $\mathrm{T}_{1}$ (Control) & $3265 \mathrm{~d}$ & $4280 \mathrm{~d}$ \\
\hline $\mathrm{T}_{2}\left(\mathrm{PU}, 104 \mathrm{~kg} \mathrm{~N} \mathrm{ha}^{-1}\right)$ & $5700 \mathrm{ab}$ & $6244 a b$ \\
\hline $\mathrm{T}_{3}$ (USG, $\left.104 \mathrm{~kg} \mathrm{~N} \mathrm{ha}^{-1}\right)$ & $5981 \mathrm{a}$ & $6381 \mathrm{a}$ \\
\hline $\mathrm{T}_{4}\left(\mathrm{USG}, 78 \mathrm{~kg} \mathrm{~N} \mathrm{ha}^{-1}\right)$ & $5533 b$ & $6057 \mathrm{ab}$ \\
\hline $\mathrm{T}_{5}$ (USG, $52 \mathrm{~kg} \mathrm{~N} \mathrm{ha}^{-1}$ ) & $5400 \mathrm{bc}$ & $5900 \mathrm{bc}$ \\
\hline $\mathrm{T}_{6}\left(\mathrm{NPK}\right.$ briquette, $\left.104 \mathrm{~kg} \mathrm{~N} \mathrm{ha}^{-1}\right)$ & $5722 \mathrm{ab}$ & 6166ab \\
\hline $\mathrm{T}_{7}\left(\mathrm{NPK}\right.$ briquettes, $78 \mathrm{~kg} \mathrm{~N} \mathrm{ha}^{-1}$ ) & $5400 \mathrm{bc}$ & $5866 \mathrm{bc}$ \\
\hline $\mathrm{T}_{8}\left(\mathrm{NPK}\right.$ briquettes, $52 \mathrm{~kg} \mathrm{~N} \mathrm{ha}^{-1}$ ) & $5100 \mathrm{c}$ & $5566 \mathrm{c}$ \\
\hline $\mathrm{CV} \%$ & 4.28 & 3.83 \\
\hline $\mathrm{SE}( \pm)$ & 130 & 129 \\
\hline
\end{tabular}

Figures in a column having common letters do not differ significantly at 5\% level of significance. CV $(\%)=$ Coefficient of variation; $\mathrm{SE}( \pm)=$ Standard error of means

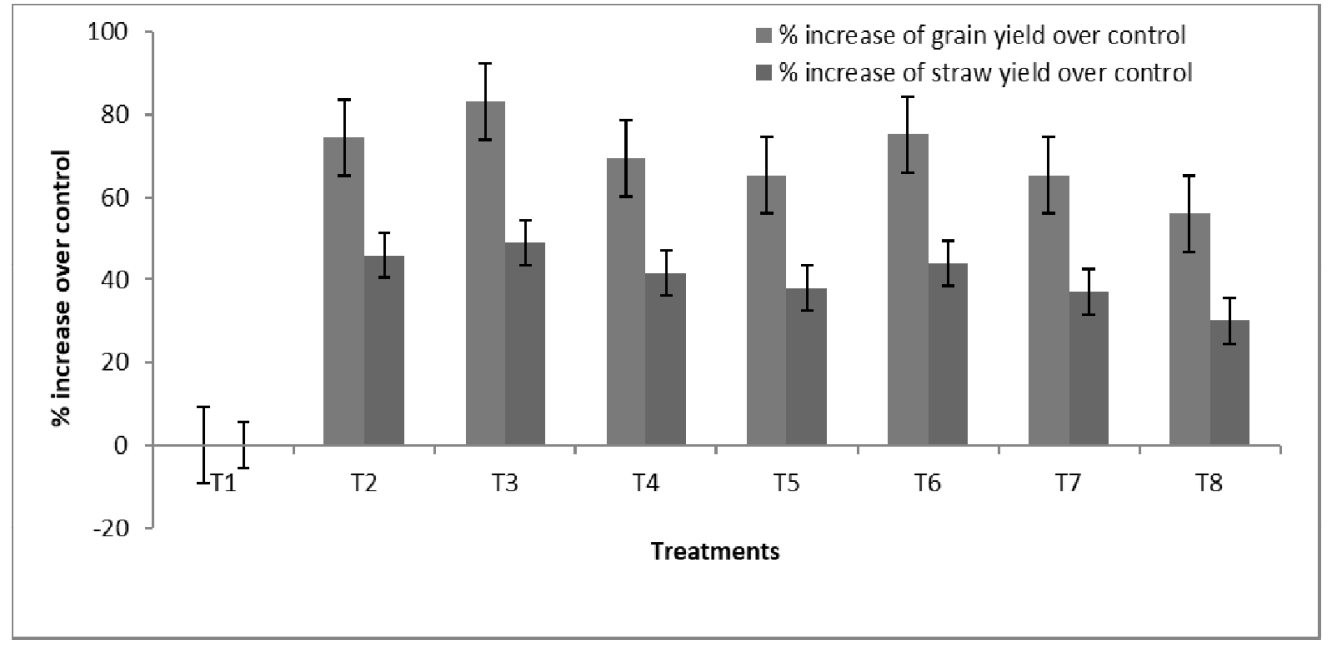

Fig. 1. Bar diagram showing \%yield increase over control of BRRI dhan 49 as influenced by the application of PU, USG and NPK briquettes

\section{Apparent $N$ recovery (ANR)}

The apparent $\mathrm{N}$ recovery (ANR) indicates the absorption efficiency of applied N. The ANR by BRRI dhan 49 has been presented in Fig. 2. Mean apparent recovery of N by BRRI dhan 49 ranged from 42.58 to $67.44 \%$ in different treatments. The maximum value of ANR was obtained with the application of USG in treatment $T_{5}$ (USG, $52 \mathrm{~kg} \mathrm{~N} \mathrm{ha}^{-1}$ ) followed by $\mathrm{T}_{3}$ (USG, $104 \mathrm{~kg} \mathrm{~N}$ ha ${ }^{1}$ ), $\mathrm{T}_{8}$ (NPK briquette, $52 \mathrm{~kg} \mathrm{~N}^{-1}$ ), $\mathrm{T}_{4}$ (USG, $78 \mathrm{~kg} \mathrm{~N}$ $\mathrm{ha}^{-1}$ ), $\mathrm{T}_{7}$ (NPK briquettes, $78 \mathrm{~kg} \mathrm{~N} \mathrm{ha}^{-1}$ ) and $\mathrm{T}_{6}$ (NPK briquettes, $104 \mathrm{~kg} \mathrm{~N} \mathrm{ha}^{-1}$ ). The minimum value was found in $\mathrm{T}_{2}\left(\mathrm{PU}, 104 \mathrm{~kg} \mathrm{~N} \mathrm{ha}^{-1}\right)$. The data show that the deep placement of USG and NPK briquettes increased the recovery of applied $\mathrm{N}$ as compared to broadcast application of NPK fertilizers in flooded condition. The results of the present study support the findings of Islam et al. (2017) and Shaha et al. (2018) who demonstrated that application of $\mathrm{N}$ in the form of USG and NPK briquette increased the apparent $\mathrm{N}$ recovery of rice as compared to PU. 


\section{Nitrogen use efficiency (NUE)}

Agronomic nitrogen use efficiency (NUE) is a term used to indicate the relative balance between the amount of fertilizer $\mathrm{N}$ taken up and used by the crop versus the amount of fertilizer $\mathrm{N}$ lost. Nitrogen use efficiency represents the responses of rice plant in terms of grain yield to $\mathrm{N}$ fertilizer. The maximum value of NUE (41.05 $\mathrm{kg}$ grain increase per $\mathrm{kg} \mathrm{N}$ applied) was obtained in $\mathrm{T}_{5}$ (USG, $\left.52 \mathrm{~kg} \mathrm{~N} \mathrm{ha}^{-1}\right)$ followed by $\mathrm{T}_{8}(35.28 \mathrm{~kg}$ grain increase per $\mathrm{kg} \mathrm{N}$ applied), $\mathrm{T}_{4}(29.08 \mathrm{~kg}$ gain increase per kg $\mathrm{N}$ applied), $\mathrm{T}_{7}(27.37 \mathrm{~kg}$ gain increase per $\mathrm{kg} \mathrm{N}$ applied), $\mathrm{T}_{3}(26.12 \mathrm{~kg}$ gain increase per $\mathrm{kg} \mathrm{N}$ applied) and $\mathrm{T}_{6}$ (23.63 $\mathrm{kg}$ gain increase per $\mathrm{kg} \mathrm{N}$ applied). The minimum value was found in $\mathrm{T}_{2}(23.41 \mathrm{~kg}$ gain increase per $\mathrm{kg} \mathrm{N}$ applied). The data clearly indicate that the deep placement of USG and NPK briquettes enhanced the NUE as compared to broadcast application of prilled urea (Fig. 2). Das et al. (2015), Islam et al. (2017) and Shaha et al. (2018) also reported that deep placement of $\mathrm{N}$ fertilizers enhanced the $\mathrm{N}$ use efficiency of rice.

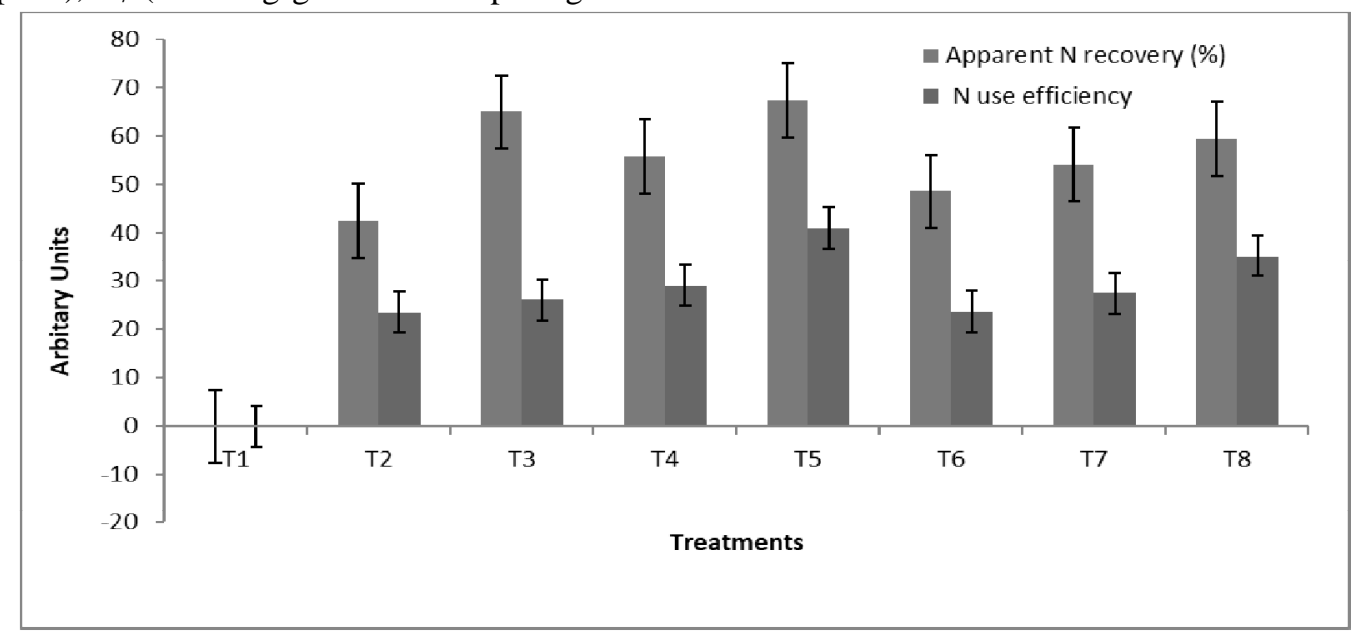

Fig. 2. Bar diagrams showing the effect of PU, USG and NPK briquettes on apparent $N$ recovery (\%) and $N$ use efficiency (NUE) of BRRI dhan49

\section{Conclusions}

The overall results indicate that the highest grain yield of BRRI dhan49 was found in $\mathrm{T}_{3}$ (USG, $104 \mathrm{~kg} \mathrm{~N} \mathrm{ha}^{-1}$ ) which was statistically similar with $\mathrm{T}_{2}$ (PU, $104 \mathrm{~kg} \mathrm{~N}^{-}$ ${ }^{1}$ ) and $\mathrm{T}_{6}$ (NPK briquettes, $104 \mathrm{~kg} \mathrm{~N} \mathrm{ha}^{-1}$ ). The maximum $\mathrm{N}$ uptake was also observed in $\mathrm{T}_{3}$. On the contrary, treatment $\mathrm{T}_{5}$ showed the maximum apparent $\mathrm{N}$ recovery and maximum $\mathrm{N}$ use efficiency as compared to other treatments. The recovery of applied $\mathrm{N}$ obtained from $\mathrm{T}_{3}$ was approximately similar to $T_{5}$. The deep placement of USG and NPK briquettes enhanced the recovery of applied $\mathrm{N}$ and $\mathrm{N}$ use efficiency in comparison with broadcast application of PU fertilizers. As a consequence, the grain yield of BRRI dhan 49 was increased to a significant extent. Based on grain yield and apparent $\mathrm{N}$ recovery, the treatment $\mathrm{T}_{3}$ (USG, $104 \mathrm{~kg}$ $\mathrm{N} \mathrm{ha}^{-1}$ ), can be recommended for the production of aman rice, BRRI dhan 49 .

\section{References}

AIS (Agriculture Information Service) 2008. Krishi Diary, AIS, Ministry of Agriculture, Govt. Peopleôs Repub. Bangladesh.
BBS (Bangladesh Bureau of Statistics) 2008. Monthly Statistical Bulletin of Bangladesh. Statistics Div. Ministry of Planning, Govt. Peopleôs Repub. Bangladesh.

Bhuiyan, N.I.; Miah, M.A.M. and Ishaque, M. 1998. Research on USG: Findings and Future Research Areas and Recommendation. Paper Presented at the National Workshop on Urea Super Granules Technology, held at BARC, Dhaka, Bangladesh, 25 June 1998.

Das, S., Islam, M.R., Sultana, M., Afroz, H. and Hashem, M.A. 2015. Effect of deep placement of nitrogen fertilizers on rice yield and $\mathrm{N}$ use efficiency under water regimes. SAARC J. Agri., 13(2): 161-172.

IFDC (International Fertilizer Development Centre) 2007. Mitigating poverty and environmental degradation through nutrient management in South Asia IFDC Report, March 2007.

Gomez, K.A. and Gomez, A.A. 1984. Statistical Procedures for Agricultural Research. John Wiley and Sons. New York. 
Islam, M.S.; Rahman, F. and Hossain, A.T.M.S. 2011. Effects of NPK Briquette on Rice (Oryza sativa) in tidal flooded ecosystem. The Agriculturists, 9(1\&2):37-43.

Islam, M.R.; Tabassum, N.; Akhter, M.T.; Hossen, K. and Hossain, M.A. 2017. Nitrogen use efficiency and yield of BRRI dhan46 as influenced by deep placement of $\mathrm{N}$ fertilizers under flooded condition. Asian Australasian Journal of Bioscience and Biotechnology, 2 (3):219-225.

Kapoor, V.; Singh, U.; Patil, S.K.; Magre, H.; Shrivastava, L.K.; Mishra, V.N., Das, R.O., Samadhiya, V.K.; Sanabria, J. and Diamond, R. 2008. Rice growth, grain yield and floodwater nutrient dynamics as affected by nutrient placement method and rate. Agronomy Journal, 100:526-536.

Khalil, M.I.; Schmidhalter, U. and Guster, R. 2009. Emissions of nitrous oxide, ammonia and carbon dioxide from a cambisol at two contrasting soil water regimes and urea granular sizes. Communications in Soil Science and Plant Analysis, 40(7-8): 1191-1213.

Mohanty, S.K.; Singh, U; Balasubramanian, V. and Iha, K.P. 1999. Nitrogen deep placement technologies for productivity, profitability and environmental quality of rainfed low land rice systems. Nutrient Cycling in Agroecosystem, 53(1):43-57.

Savant, N.K. and Stangel, P.J. 1990. Deep placement of urea super granule in transplanted rice: principles and practices. Fertilizer Research, 25:1-83.

Shaha, S., Islam, M.R., Islam, M.R., Akhter, M.T. and Siddique, A.B. 2018. Efficacy of deep placement of nitrogen fertilizers on $\mathrm{N}$ use efficiency and yield of boro rice (cv. BRRI Dhan29). American J. Agric. Res. 3:21.

Zhu, Z.L.; Wen, Q.X. and Freney, J.R. 1997. Nitrogen in Soils of China. Kluwer Academic Publishers, Dordrecht. 